\title{
Perceptions of the Physical and Social Neighbourhood Environment and Youth Volunteerism: Canada's Capital Region
}

\author{
Sean Pearce \& Elizabeth Kristjansson \\ University of Ottawa
}

\begin{abstract}
Youth are embedded within various ecological systems that may impact their philanthropic behaviour. This study employed online data from a sample of undergraduate students and traced the various pathways through which neighbourhood perceptions (e.g., social cohesion, satisfaction with amenities) related to formal and informal volunteering intensities. Path analyses revealed that neighbourhood cohesion directly predicted formal and informal volunteer frequency; as well, it mediated the relationship between satisfaction with neighbourhood amenities and informal volunteerism. Neighbourhood cohesion was strongly associated with informal volunteer intensity, whereas satisfaction with neighbourhood attractiveness did not relate to any volunteer outcomes. Neighbourhood characteristics may be important drivers of youth volunteerism, and thus stakeholders, organizations, and individuals should consider the impact of the social environmental context on shaping youths' helping behaviour.
\end{abstract}

\section{RÉSUMÉ}

Les jeunes font partie de divers systèmes écologiques qui peuvent influencer leur comportement philanthropique. Cette étude utilise des données recueillies en ligne à partir d'un échantillon d'étudiants de premier cycle afin de retracer les divers parcours par lesquels leur perception de leur quartier (par exemple, sa cohésion sociale, leur satisfaction par rapport aux services offerts) a une incidence sur leurs activités bénévoles formelles et informelles. L'analyse révèle que la cohésion sociale a comme effet d'augmenter le bénévolat formel et informel. En outre, la cohésion semble augmenter le bénévolat informel là où il y a satisfaction par rapport aux services offerts dans la communauté. En effet, il y a une forte corrélation entre la cohésion d'un quartier et le bénévolat informel. En revanche, la satisfaction à l'égard du pittoresque d'un quartier ne paraît pas avoir d'incidence sur le niveau d'implication philanthropique. II n'empêche qu'en général un bon quartier peut motiver les jeunes à faire du bénévolat. Ainsi, les parties prenantes, les organisations et les individus devraient tenir compte du contexte socioenvironnemental sur le comportement philanthropique des jeunes.

Keywords / Mots clés Volunteering; Youth; Neighbourhoods; Informal volunteering; Cohesion / Bénévolat; Jeunesse; Quartiers; Bénévolat informel; Cohésion 


\section{Pearce \& Kristjansson (2019)}

\section{INTRODUCTION}

A subjective appraisal of one's neighbourhood may be linked to an array of youth outcomes and behaviours (e.g., mental health, academic achievements) beyond what geographic information systems or other objective measures can reveal (e.g., Eamon \& Mulder, 2005; Forehand \& Jones, 2003; Plybon, Edwards, Butler, Belgrave, \& Allison, 2006). Since neighbourhoods can be incorporated in an individual's identity, the image and perceptions of one's neighbourhood may be crucial to how one interacts within the local living space (Forrest \& Kearns, 2001). For example, neighbourhood attributes may influence the degree to which residents give their time freely to organizations and help others in their neighbourhood. The present study examines the relative contribution of perceived neighbourhood cohesion, neighbourhood satisfaction, and neighbourhood problems on youths' volunteering intensities. It also explores the potential interrelationships between these variables. Despite the abundance of literature on neighbourhoods and youth outcomes (e.g., delinquency, physical activity), there is very minimal research on the relations between the neighbourhood environment and youth volunteerism.

Volunteering can be defined as an activity that is usually planned rather than spontaneous, and where time is given to benefit others; it also generally does not involve any remuneration (e.g., Snyder \& Omoto, 2007; Wilson, 2000). Specifically, formal volunteering is unpaid help on behalf of an organization (e.g., Carson, 1999; Wilson \& Musick, 1997), whereas informal volunteering is less structured and may involve helping neighbours and friends directly outside an organizational context (e.g., Finkelstein \& Brannick, 2007; Lee \& Brudney, 2012). Volunteering is particularly important for youth, as it allows them to acquire valuable skills (e.g., leadership, career), build social connections, and enhance prosocial attitudes (e.g., Lerner et al., 2005; Siu, Shek, \& Law, 2012). There is mounting evidence that volunteerism is linked to positive youth development, including increased confidence, competency, and compassion (e.g., Feldman \& Matjasko, 2005; Gardner, Roth, \& Brooks-Gunn, 2008), and recently it was shown that youth who volunteered during adolescence had higher wages in young adulthood (Kim \& Morgül, 2017). It is well established that social networks and friendships are important catalysts for formal and informal volunteerism (e.g., Lee \& Brudney, 2012; Wilson \& Musick, 1997), especially for youth (e.g., McLellan \& Youniss, 2003; Sundeen \& Raskoff, 2000). Vast literature shows that youth who have parents who volunteer are more likely to volunteer themselves, as are youth who are part of religious institutions (e.g., Bekkers, 2007; Gibson, 2008; Pancer \& Pratt, 1999). Taken together, social cohesion in the neighbourhood may be fundamental to informal youth volunteering because this type of volunteering may involve directly helping familiar faces in one's neighbourhood. Social cohesion may also be related to formal volunteering because youth who have stronger feelings of belongingness may wish to build their communities through participation in local organizations. Further, given that schools and extracurricular programs are important avenues to initiate youth volunteering (e.g., Pancer \& Pratt, 1999; Zaff, Moore, Papillo, \& Williams, 2003), having access to and being satisfied with a variety of neighbourhood amenities should promote volunteerism.

It should be noted that youth volunteer for many different reasons, including social and career-oriented motives (Holdsworth \& Quinn, 2010; Tessier, Minh-Nguyet, \& Gagnon, 2006), as well as wanting to make a difference and feel productive (MacNeela \& Gannon, 2014). One study found that diverse young volunteers could be categorized into four groups based on motivations to volunteer: instrumental (e.g., building skills), personal (e.g., emotionally affected by a cause), weak motives (e.g., volunteering was required), and helping identity (e.g., wanting to help others; Ballard, Malin, Porter, Colby, \& Damon, 2015). Volunteering intensities may be impacted by motivations, as one study showed that students who volunteered to build their résumé tended to invest less time into volunteering than those who had more altruistic motivations (Handy et al., 2010). In a sample of undergraduate students, it was found that scores on collectivism—characterized by greater concern for community over personal identity -was related to higher informal volunteering frequency (Finkelstein, 2012). Though youth often cite several motives for volunteering, youth with stronger feelings of social cohesion may be especially more inclined to volunteer because it may be part of their identity to contribute to the greater good. 


\section{DEFINING NEIGHBOURHOOD COHESION: A BRIEF OVERVIEW}

The literature is rife with different meanings and definitions of social cohesion, which has stirred criticism on how to properly understand and study such a diverse concept (Chan, To, \& Chan, 2006). Many researchers adopt multidimensional conceptualizations of this construct rather than adhering to a strict set of criteria and principles. Neighbourhood social cohesion has been defined as feelings of connectedness and mutual support between people in a community, as well as the cooperative manner in which they interact (e.g., Buckner, 1988; Obasaju, Palin, Jacobs, Anderson, \& Kaslow, 2009; Sampson, Raudenbush, \& Earls, 1997). Social cohesion is concomitant with liberal values of inclusion, freedom, tolerance, and equity (Stanley, 2003), and encompasses ideas such as trust, norms of reciprocity, communal values, and the strength of associations that tie people together (e.g., Bruhn, 2009; Chan et al., 2006; Sampson, 1997). Key tenets of social cohesion include: social networks, active participation, trust and reciprocity, safety, attraction to the neighbourhood, and sense of community (Dempsey, 2008).

The origins of a sense of community trace back to Seymour Sarason (1974), who posited that feelings of kinship, shared values, and reduced feelings of loneliness comprise the essence of this construct. A sense of community is composed of many elements, such as feeling a sense of belonging and caring for one another, and the belief that community needs will be met through commitment to other group members (McMillan \& Chavis, 1986). Cohesive groups have feelings of belongingness, "we-ness," and members work in harmony to attain a common goal (e.g., Buckner, 1988; Hartman, 1981). These constituents of social cohesion have overlapping elements, namely that relationships and emotional bonds with other group members are essential for fostering social cohesion. In this article, neighbourhood cohesion and social cohesion are used interchangeably as they are not clearly distinct in the literature.

It is worthwhile to consider the bonding and bridging dynamics of social cohesion. According to Robert Putnam (2000), bonding ties include strong ties with homogeneous groups (e.g., people of similar religion, ethnicity), whereas bridging ties involve affiliations with diverse or heterogeneous groups. Bonding ties are important for social cohesion. People who share similar values and beliefs with other community members may band together because homophilic bonds nurture stronger connections (e.g., McPherson, Smith-Lovin, \& Cook, 2001). However, the bonding of homogeneous groups could lead to the marginalization and social exclusion of other potential group members. There is voluminous, yet controversial, literature indicating that residents in heterogeneous neighbourhoods have lower interpersonal trust, which is one facet of social cohesion (e.g., Alesina \& La Ferrara, 2005; Costa \& Kahn, 2003; Stolle, Soroka, \& Johnston, 2008). Notably, Putnam (2007) used data from a nationwide survey in the U.S, and found that people in ethnically diverse neighbourhoods had lower social trust in people of other races and their own race, lower likelihood of donating and volunteering, and fewer close companions than those in less diverse neighbourhoods. Putnam argued that, in the short term, diversity can make people withdraw from their communities and "hunker down" in the manner of turtles. Similar patterns have emerged in Canada; visible minorities reported a weaker sense of belonging and interpersonal trust than British/Northern Europeans (Soroka, Johnston, \& Banting, 2006). This research suggests that bridging relationships between dissimilar social groups are important to help prevent potential social isolation. Though the purpose of the present study is not to directly explore neighbourhood diversity, in light of the expanding multiculturalism in Canada, it is imperative to explore how perceptions of neighbourhood cohesion are related to voluntary behaviour because volunteerism itself can "bridge" divided groups and communities (Soroka et al., 2006).

\section{NEIGHBOURHOOD COHESION, SATISFACTION, AND COMMUNITY PARTICIPATION}

Recently, there has been a prolific emergence of research on the impact of neighbourhood characteristics on social cohesion and residential satisfaction. Several positive physical properties of the neighbourhood, including shops, cafés, trees, green space, and aesthetics impact residential satisfaction (e.g., Andersen, 2008; Braubach, 2007; Young, Russel, 


\section{Pearce \& Kristjansson (2019)}

\& Powers, 2004), while perceptions of high crime and low safety may reduce neighbourhood satisfaction (e.g., Parkes, Kearns, \& Atkinson, 2002). Physical disorder may incite negative feelings toward one's neighbourhood (e.g., Sampson \& Raudenbush, 1999), whereas the cleanliness of the environment has been associated with higher neighbourhood satisfaction (e.g., Adriaanse, 2007; Aiello, Ardone, \& Scopelliti, 2010; Parkes et al., 2002).

Residents who have greater community satisfaction also tend to have stronger feelings of cohesion and an enhanced sense of belonging (e.g., Grzeskowiak, Sirgy, \& Widgery, 2003; Hand, Law, Hanna, Elliot, \& McColl, 2012). Neighbourhood cohesion, in turn, is linked to higher community participation, whereas neighbourhood problems are often related to lower participation (e.g., Bowling \& Stafford, 2007; Glass \& Balfour, 2003). One study suggests that social cohesion mediates the relationship between the positive characteristics of the built environment (e.g., walkable sidewalks, minimal litter) and greater community participation (King, 2008). Neighbourhoods with a higher number of facilities may be more cohesive because they offer more opportunities to socialize (Völker, Flap, \& Lindenberg, 2007). Positive perceptions of the userfriendliness of neighbourhoods (e.g., social environment, walkability) should mobilize community participation because this facilitates easier contact with others.

Positive perceptions of neighbourhood safety also influence community participation (e.g., Glass \& Balfour, 2003; Hovbrandt, Stahl, Iwarsson, Horstmann, \& Carlsson, 2007). Living in neighbourhoods with a high level of incivilities (e.g., crime, graffiti) may erode social cohesion because it reduces social interactions in the neighbourhood (e.g., Clarke, Ailshire, Nieuwenhuijsen, \& de Kleijn-de Vrankrijker, 2011; Letki, 2008), and may evoke fear in people (e.g., Lorenc et al., 2012; Sampson, Morenoff, \& Gannon-Rowley, 2002). According to James Wilson and George Kelling's (1982) "broken windows" theory, dilapidated or unclean neighbourhoods may signal disorder, which can lead to the depletion of social exchanges in the neighbourhood due to inhabitants feeling unsafe. This rich body of scholarship strongly suggests that the environmental context impacts neighbourhood satisfaction, feelings of social cohesion, and community engagement.

\section{NEIGHBOURHOOD PERCEPTIONS AND VOLUNTEERISM}

Various neighbourhood attributes have also been associated with volunteer behaviour, though much of this research has focused on older adults. Research has shown that older adults were more involved in formal activities if they perceived greater volunteer opportunities in their neighbourhood and had frequent contact with neighbours (Buffel, De Donder, Phillipson, Dury, De Witte, \& Verté, 2013), and if they felt connected, safe, and lived in neighbourhoods with more amenities (Dury, Willems, De Witte, De Donder, Buffel, \& Verté, 2014), including greater access to transportation (Bowling \& Stafford, 2007). In one study, older adults in Québec, Canada, were more likely to volunteer if they felt stronger neighbourhood belonging and perceived greater accessibility to neighbourhood resources (e.g., restaurants, shops; Richard, Gauvin, Gosselin, \& LaForest, 2008). This study did not, however, clearly define volunteering with regard to whether it was limited to organizations or included informal volunteering.

Neighbourhood social cohesion may be fundamental to volunteerism with studies showing a relationship between a stronger sense of community and greater participation in voluntary associations and organizations (e.g., Okun \& Michel, 2006). Relatedly, older adults who are very satisfied with their community interactions (e.g., with neighbours, friends) are more likely to formally and informally volunteer (Ahn, Phillips, Smith, \& Ory, 2011). While neighbourhood satisfaction is related to social cohesion and community participation, low satisfaction may also be an impetus for activism. In one study, residents who were less satisfied with their neighbourhood were more likely to volunteer, suggesting that these residents may have volunteered to improve their neighbourhood (Dury et al., 2014). 


\section{NEIGHBOURHOOD PERCEPTIONS AND YOUTH VOLUNTEERISM}

Little is known about the pathways between neighbourhood perceptions and youth volunteerism. Some research supports the idea that neighbourhood social capital (e.g., community trust) is related to youths' civic engagement (Lenzi Vieno, Perkins, Santinello, Elgar, Morgan, \& Mazzardis, 2012). Different neighbourhood characteristics may also interact with personal attributes to influence philanthropic behaviour. Among a sample of adolescents, a sense of community and perceived neighbourhood and city concerns (e.g., job availability, safety) were differentially related to volunteerism depending on ethnicity (Kegler, Oman, Vesely, McLeroy, Aspy, Rodine, \& Marshall, 2005). Specifically, community involvement was related to neighbourhood safety for African Americans and to a sense of community for Native Americans. Generally, strong community identity should encourage youth to strive for collective action and solve community problems together. Indeed, one study revealed that students' sense of community connectedness predicted intentions to participate in community service (Hellman, Hoppes, \& Ellison, 2006).

Naomi Duke, Iris Borowsky, and Sandra Pettingell (2012) found that parental perceptions of neighbourhood social capital and resource availability (e.g., recreational centres, walking paths) related to youths' higher volunteer frequency. In this study, there was no relationship between perceived physical disorder and youth volunteering. Neighbourhood perceptions, however, were only based on parents' responses. Further, the ubiquity of litter in streets and parks has been related to weakened productive relationships among residents (e.g., Sampson et al., 1997). Residents who feel they live in disordered neighbourhoods may have weaker social cohesion and thus may be disinvested in constructive community activities.

The literature on youth volunteerism and neighbourhood perceptions is underexplored. This study attempts to gain a better understanding of the relations between the characteristics of place and community engagement. The models examine the perceptions of neighbourhood problems (e.g., litter) and neighbourhood satisfaction (e.g., facilities, streets) as precursors to neighbourhood cohesion. Theoretically, feeling safe in an aesthetically pleasing neighbourhood with more facilities in which to socialize would seem to foster cohesion.

\section{HYPOTHESIS}

Lower perceived neighbourhood problems and higher neighbourhood satisfaction will relate to higher neighbourhood cohesion. These neighbourhood attributes, as well as cohesion, will relate to higher formal and informal volunteer intensity.

\section{METHOD}

\section{Participants}

This study comprised a sample of undergraduate students from a Canadian university, located in the city of Ottawa $(N=306)$. Participants had to have lived in the same neighbourhood for at least one year, so they were familiar with their neighbourhood (and to ensure that if they volunteered within the last year, it was in the same neighbourhood). Participants completed online questionnaires from FluidSurveys and received course credits for their participation.

Participants were aged 17-24 ( $M=19.36, S D=1.55)$. Seventy-eight percent of the sample were female and 22 percent were male. Approximately one-third were in the highest household income category of $\$ 100,000$ or more (32\%), and 77 percent had worked within the past 12 months. Over one-third identified as a visible minority (37\%), and many had lived ten years or longer in their current community $(42 \%)$.

\section{MEASURES}

\section{Neighbourhood cohesion}

Neighbourhood cohesion was measured using John C. Buckner's (1988) Neighbourhood Cohesion Instrument, which 
can be understood as one scale comprising three dimensions: neighbourliness, neighbourhood attraction, and sense of community. This 18-item scale has very high test-retest reliability $(\alpha=0.95)$ and internal consistency $(\alpha=0.95)$. It was also able to discriminate among three disparate neighbourhoods (Buckner, 1988). All items are presented on a five-point Likert scale. For ease of interpretation, the scale was reversed ( $1=$ strongly disagree to $5=$ strongly agree). A Principal Component Analysis (PCA) was conducted and the scree plot, as well as the cumulative variance of 96 percent, suggested that a one-factor solution be retained. The scale had high reliability $(\alpha=0.91)$.

\section{Neighbourhood problems}

Participants' perceptions of neighbourhood problems were assessed using a questionnaire from Anne Ellaway, Sally Macintyre, and Ade Kearns (2001). This 12-item scale used Likert rating (1 = not at all a problem, 2 = minor problem, 3 = major problem). The scale was reversed for statistical purposes: higher scores meant a more positive perception of one's neighbourhood. Items that did not seem to reflect Ottawa were modified (e.g., "Presence of needles/syringes" was replaced with "Presence of cigarette butts or beer bottles"). A PCA with a two-fixed component solution was run because the scree plot suggested only two components, which was more interpretable (Table 1). The two factors explained 51 percent of the variance. Each scale was summed and averaged to yield final scores. Component 1 (Environmental Problems) consisted of seven items (e.g., "Vandalism", "Smells/fumes"; $a=0.84$ ). Component 2 (Safety Problems) comprised five items (e.g., "Disturbance from children or youngsters," "Uneven or dangerous pavements"; $a=0.70$ ).

Table 1: Factor loadings for Principal Component Analysis with Varimax rotation of perceived neighbourhood problems

\begin{tabular}{|l|c|c|}
\hline Items & Environment problems & Safety problems \\
\hline Vandalism & .76 & .11 \\
\hline Litter and rubbish & .73 & .14 \\
\hline Presence of panhandlers or shady characters & .77 & .08 \\
\hline Speeding traffic & .48 & .10 \\
\hline Reputation of neighbourhood & .64 & .31 \\
\hline Smells/fumes & .66 & .25 \\
\hline Cigarette butts or beer bottles & .77 & .18 \\
\hline Burglaries & .59 & $.38^{*}$ \\
\hline Lack of safe places for children to play & .47 & .58 \\
\hline Disturbance by children or youngsters & .27 & .42 \\
\hline Uneven or dangerous pavements & .28 & .63 \\
\hline Lack of recreational facilities & .02 & .84 \\
\hline
\end{tabular}

Notes: Factor loadings > .40 are in boldface. *This item had a factor loading $<.40$ on the safety problems subscale but was included in this factor based on theoretical reasoning.

\section{Neighbourhood satisfaction}

A questionnaire from the European Commission (2013) was adapted for this study as there was no validated scale applicable to a Canadian context. Participants were asked to rate their level of satisfaction with 12 different neighbourhood features $(1=$ not at all satisfied to $4=$ very satisfied). A PCA with Varimax rotation was conducted (Table 2$)$. The scree 
plot, the number of eigenvalues greater than one, and variance explained $(50 \%)$ suggested a two-component solution. Component 1 (Satisfaction with Neighbourhood amenities) consisted of seven items (e.g. "Availability of public spaces, such as markets and pedestrian areas"; $a=0.80$ ). One item with a cross loading ("Availability of good quality, affordable food") was included in this subscale as it was considered an amenity. Component 2 (Satisfaction with Neighbourhood attractiveness) comprised five items (e.g. "The state of the streets," "The state of buildings"; $a=0.78$ ).

Table 2: Factor loadings for Principal Component Analysis with Varimax rotation of neighbourhood satisfaction items

\begin{tabular}{|l|c|c|}
\hline Items & $\begin{array}{c}\text { Neighbourhood } \\
\text { amenities }\end{array}$ & $\begin{array}{c}\text { Neighbourhood } \\
\text { attractiveness }\end{array}$ \\
\hline Public transit (e.g., buses) & .59 & .18 \\
\hline Availability of libraries or cultural centres & .67 & .11 \\
\hline Availability of retail shops & .72 & .14 \\
\hline Schools and other educational facilities & .77 & .08 \\
\hline Availability of sports facilities, such as recreational centres or gyms & .68 & .17 \\
\hline Availability of public spaces, such as markets and pedestrian areas & .59 & .29 \\
\hline Availability of good-quality, affordable food & $.43^{*}$ & .50 \\
\hline Availability of green spaces (e.g., parks) & .18 & .57 \\
\hline The state of buildings & .21 & .74 \\
\hline Cleanliness (e.g., does it lack vandalism, litter?) & .05 & .80 \\
\hline The state of sidewalks, trails, and walking paths & .26 & .71 \\
\hline The state of the streets & .15 & .71 \\
\hline
\end{tabular}

Notes: Factor loadings $>.40$ are in boldface. ${ }^{*}$ This item had a cross-loading but was included in the neighbourhood amenities subscale based on theoretical reasoning.

\section{Formal and informal volunteering}

Variables on volunteering were adopted from the Canada Survey of Giving, Volunteering and Participating (CSGVP; Statistics Canada, 2007). Formal volunteering frequency was based on how often participants volunteered without pay on behalf of an organization within the last 12 months $(1=$ not at all to $6=$ daily or almost daily). For informal volunteering, participants were asked: "In the past month how often did you help relatives, neighbours, friends, or community members (who live outside your home) with activities that were not on behalf of an organization?" This was assessed on a fourpoint Likert scale $(1=$ did not informally volunteer to $4=$ daily or almost daily). Informal activities may be less structured and less time-consuming, and thus a shorter time frame would improve the accuracy in which participants remembered these activities.

\section{STATISTICAL ANALYSIS}

After the PCA revealed two components for neighbourhood satisfaction, satisfaction with neighbourhood amenities and satisfaction with neighbourhood attractiveness were considered in separate models, though the direction of the hypothesis 


\section{Pearce \& Kristjansson (2019)}

remained the same. Theoretically, these components appear to be distinct; neighbourhood amenities may be more strongly associated with neighbourhood cohesion because of greater opportunities for social interactions. The models also included the length of time residing in the community. People who live longer in their community may have a stronger sense of place identity and more social networks, making them more driven to collective action and welfare (e.g., FleuryBahi, Felonneau, \& Marchand, 2008; Prezza, Amici, Roberti, \& Tedeschi, 2001; Young et al., 2004).

\section{Model 1}

$H 1$ : All variables, including satisfaction with neighbourhood amenities, will directly predict neighbourhood cohesion, as well as informal and formal volunteer outcomes.

$H 2$ : Neighbourhood cohesion will mediate the relationship between neighbourhood amenities and formal and informal volunteer intensity.

\section{Model 2}

$H 3$ : All variables, including satisfaction with neighbourhood attractiveness, will directly predict neighbourhood cohesion, as well as informal and formal volunteer outcomes.

H4: Neighbourhood cohesion will mediate the relationship between neighbourhood attractiveness and formal and informal volunteer intensity.

Path analyses were conducted in Stata software version 14.0 to estimate model parameters by using standardized correlation matrices. All variables in the models were manifest (i.e., observed) variables. The following indices of model fit were assessed: root mean square error of approximation (RMSEA), likelihood-ratio $X^{2}$ goodness-of-fit test, relative $X^{2}$ index ( $\left.X^{2} / d f\right)$, comparative fit index (CFI), Tucker-Lewis Index (TLI), and the standard root mean squared residual (SRMR; see Hooper, Coughlan, \& Mullen, 2008 for guidelines). Briefly, a RMSEA of 0.05 is considered moderate to some researchers (e.g., MacCallum, Browne, \& Sugawara, 1996), and to others, any value below 0.08 is reasonable (e.g., Browne \& Cudeck, 1992; Kline, 2005). A relative chi-square of less than five is considered adequate (Schumacker \& Lomax, 2004; Wheaton, Muthén, Alwin, \& Summers, 1977), and a model where the degrees of freedom is close to the chi-square value is also considered adequate (e.g., Thacker, Fields, \& Tetrick, 1989). Some researchers suggest that the TLI and CFI should be greater than 0.95 and the SRMR less than 0.08 (see review by Hu \& Bentler, 1999).

To test possible mediation within different parts of the paths, bootstrapping was used to obtain precise standard errors and bias-corrected confidence intervals (MacKinnon, Lockwood, \& Williams, 2004; Preacher \& Hayes, 2008). This method is powerful for obtaining accurate confidence intervals for indirect effects (e.g., Williams \& MacKinnon, 2008), and it has stronger power, greater ability to prevent type one error, and is more useful for smaller samples (MacKinnon et al., 2004; Preacher \& Hayes 2004, 2008). Bootstrapping methods are more accurate than methods that "assume symmetry and normality of the sampling distribution of the indirect effect" (Preacher \& Hayes, 2008, p. 884). An effect was considered significant if its confidence interval did not include zero.

\section{RESULTS}

\section{Demographics and socio-demographics}

On average, respondents were neutral (neither agreed nor disagreed) about their feelings of neighbourhood cohesion $(M=2.99, S D=0.70)$. The youth scored relatively high on satisfaction with neighbourhood amenities $(M=3.15, S D=0.54)$ and satisfaction with neighbourhood attractiveness $(M=3.24, S D=0.53)$. Youth also felt that neighbourhood environment problems were minor $(M=2.56, S D=0.44)$, as were safety problems $(M=2.64, S D=0.37)$. 
Age was unrelated to informal volunteering $(r=0.07, p>.05)$, nor was it related to formal volunteering $(r=-0.05, p>.05)$. There were no gender differences in informal volunteering, $t(302)=0.40, p>.05$, or formal volunteering, $t(302)=-1.26$, $p>.05$. There was no difference between visible minorities and Caucasian youth in either formal volunteering, $t(303)=0.06$, $p>.05$, or informal volunteering, $t(305)=-0.76, p>.05$. A one-way ANOVA revealed no difference between groups according to religious attendance (no attendance, one to four times a year, monthly, weekly), either in their informal volunteering, $F(3,302)=1.25, p>.05$, or their formal volunteering, $F(3,300)=2.07, p>.05$. Residents' economic conditions may impact on their social cohesion and neighbourhood satisfaction. In this sample, however, there was no difference between household income groups (less than $\$ 20,000 ; \$ 20,000-\$ 39,999 ; \$ 40,000-\$ 59,999 ; \$ 60,000-\$ 99,999 ; \$ 100,000$ or more; and not stated) in neighbourhood cohesion, $F(5,300)=1.18, p>.05$. Further, neighbourhood satisfaction with amenities did not differ by income group, $F(5,300)=0.74, p>.05$, nor did satisfaction with neighbourhood attractiveness, $F(5,300)=1.92, p>.05$. Therefore, none of these variables were used as covariates in the path models.

\section{PATH MODELS}

\section{Model 1: Satisfaction with neighbourhood amenities}

Model 1 was identified because the number of parameters did not exceed the number of observations (Kline, 2005). After running the model, null parameter estimates were found for direct paths from safety and environment problems to formal volunteering ( $z=-1.58$ and 0.20 , respectively) and to informal volunteering ( $z=-1.24$ and -1.04 , respectively). To consider more parsimonious models, direct pathways were eliminated (i.e., the paths were constrained to zero) from neighbourhood problems to volunteer outcomes (Model 3).

\section{Figure 1: Path diagram tracing perceptions of neighbourhood characteristics, including satisfaction with neighbourhood amenities to volunteering intensity outcomes}

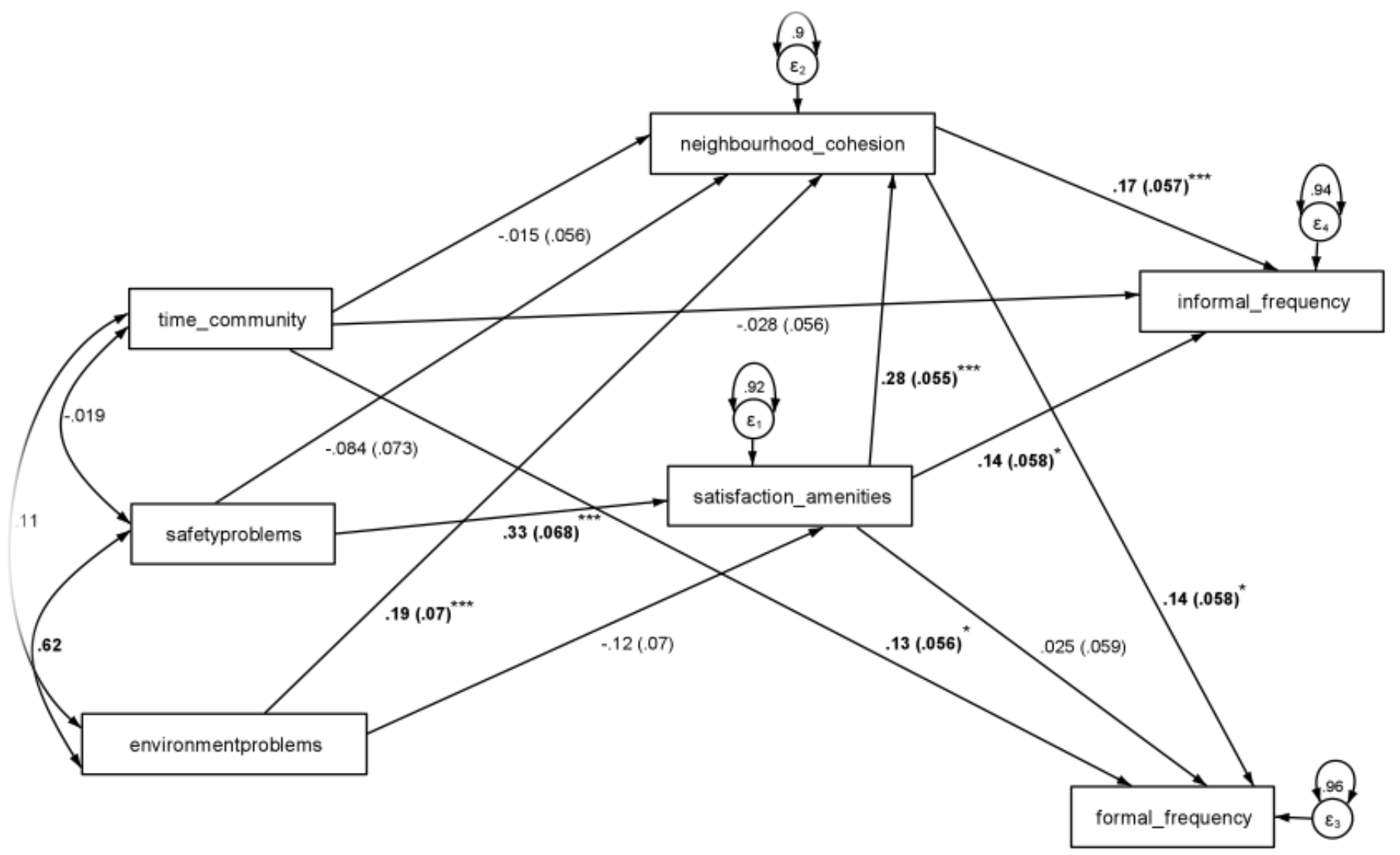

Notes: Satisfaction with neighbourhood amenities is included in this model; parameters are followed by standard errors; ${ }^{*} p<.05,{ }^{* * *} p<.001$ 
This revised model (Model 3) demonstrated a better fit than Model 1 for most of the indices (RMSEA $=0.04, C F I=0.96$, SRMR $=0.03)$. This difference in model fit was significant $\left(\operatorname{LR} X^{2}=5.11, d f=4, p>.05\right)$. The difference in the Bayesian information criterion $(\mathrm{BIC})$ between the two models also suggested that Model 3 was the better fit $\left(\mathrm{BIC}_{\mathrm{i}}=4722.72\right.$; $\left.\mathrm{BIC}_{\text {min }}=4705.01 ; \triangle \mathrm{BIC}=17.71\right)$. A lower $\mathrm{BIC}$ reflects a better fit, and a difference greater than 10 in criterion values constitutes a very strong difference (Kass \& Raftery, 1995).

Figure 1 shows the pathways leading to informal and formal volunteer frequency for Model 3. Lower perceived neighbourhood safety problems related to greater satisfaction with neighbourhood amenities $(\beta=0.33, p<.05)$, while lower perceived environment problems were associated with stronger neighbourhood cohesion $(\beta=0.19, p<.05)$. H1 was not fully supported because only neighbourhood cohesion subsequently predicted higher informal and formal volunteer intensity ( $\beta=0.17$ and 0.14 , respectively), while satisfaction with neighbourhood amenities had a direct path to informal volunteering $(\beta=0.14, p<.05)$ but not formal volunteering $(\beta=0.03, p>.05)$. Neighbourhood cohesion partially mediated the path from satisfaction with amenities to informal volunteering $(\beta=0.05, S E=0.02,95 \% \mathrm{Cl}[0.02,0.08])$, but not formal volunteering, thus $H 2$ was not fully supported.

\section{Model 2: Satisfaction with neighbourhood attractiveness}

Model 2 had fairly good fit, but similar to the first model, there were no direct paths from perceived neighbourhood problems to informal and formal volunteering, thus these paths were removed to consider a more parsimonious model (Model 4). This revised model had a better fit (RMSEA $=0.03, \mathrm{CFI}=0.99, \mathrm{SRMR}=0.03$ ) and this improvement was significant $\left(\mathrm{LR} X^{2}=3.01, \mathrm{df}=4, p>\right.$.05). The difference in $\mathrm{BIC}$ was also considered very strong $\left(\mathrm{BIC}_{\mathrm{i}}=4662.78 ; \mathrm{BIC}_{\mathrm{min}}=\right.$ 4642.98; $\triangle \mathrm{BIC}=19.80$ ). Table 3 shows a comparison of fit indices across all of the models (i.e., original and revised).

Table 3: Comparing indices across each proposed model $(N=300)$

\begin{tabular}{|l|c|c|c|c|c|c|}
\hline & Likelihood-Ratio-Test & $\begin{array}{c}\text { Relative } X^{2} \\
\text { Index }\end{array}$ & $\begin{array}{c}\text { RMSEA } \\
{[90 \% \mathrm{Cl}]}\end{array}$ & CFI & TLI & SRMR \\
\hline Model 1 (amenities) & $X^{2}(2)=4.16, p=.12$ & 2.08 & $0.06[0.00,0.14]$ & 0.97 & 0.74 & 0.02 \\
\hline Model 2 (attractiveness) & $X^{2}(2)=4.70, p=.10$ & 2.35 & $0.07[0.00,0.15]$ & 0.98 & 0.79 & 0.02 \\
\hline Model 3 (amenities revised) & $X^{2}(6)=9.26, p=.16$ & 1.54 & $0.04[0.00,0.09]$ & 0.96 & 0.87 & 0.03 \\
\hline Model 4 (attractiveness revised) & $X^{2}(6)=7.72, p=.26$ & 1.29 & $0.03[0.00,0.08]$ & 0.99 & 0.95 & 0.03 \\
\hline
\end{tabular}

Notes: RMSEA = Root mean square error of approximation; $\mathrm{Cl}=$ confidence interval around the RMSEA; CFI = Comparative fit index; $\mathrm{TLI}=$ Tucker-Lewis Index; SRMR = Standardized root mean square residual. Model 3 had a better fit than Model 1 and Model 4 had a better fit than Model 2.

As shown in Figure 2, neighbourhood safety and environment problems were related to satisfaction with neighbourhood attractiveness ( $\beta=0.19$ and 0.32 , respectively) but were not associated with neighbourhood cohesion. Although satisfaction with neighbourhood attractiveness was related to neighbourhood cohesion $(\beta=0.19, p<.05)$, it was not related to informal or formal volunteering, and therefore $\mathrm{H} 3$ was not fully supported. Neighbourhood cohesion did not mediate the relationship between satisfaction with neighbourhood attractiveness and volunteer outcomes (H4 was not supported). All other pathways leading to volunteer outcomes were similar to the model that included satisfaction with neighbourhood amenities (i.e., Model 3). It is of note that the size of the effects was relatively small. 
Figure 2. Path diagram tracing perceptions of neighbourhood characteristics, including satisfaction with neighbourhood attractiveness to volunteering intensity outcomes

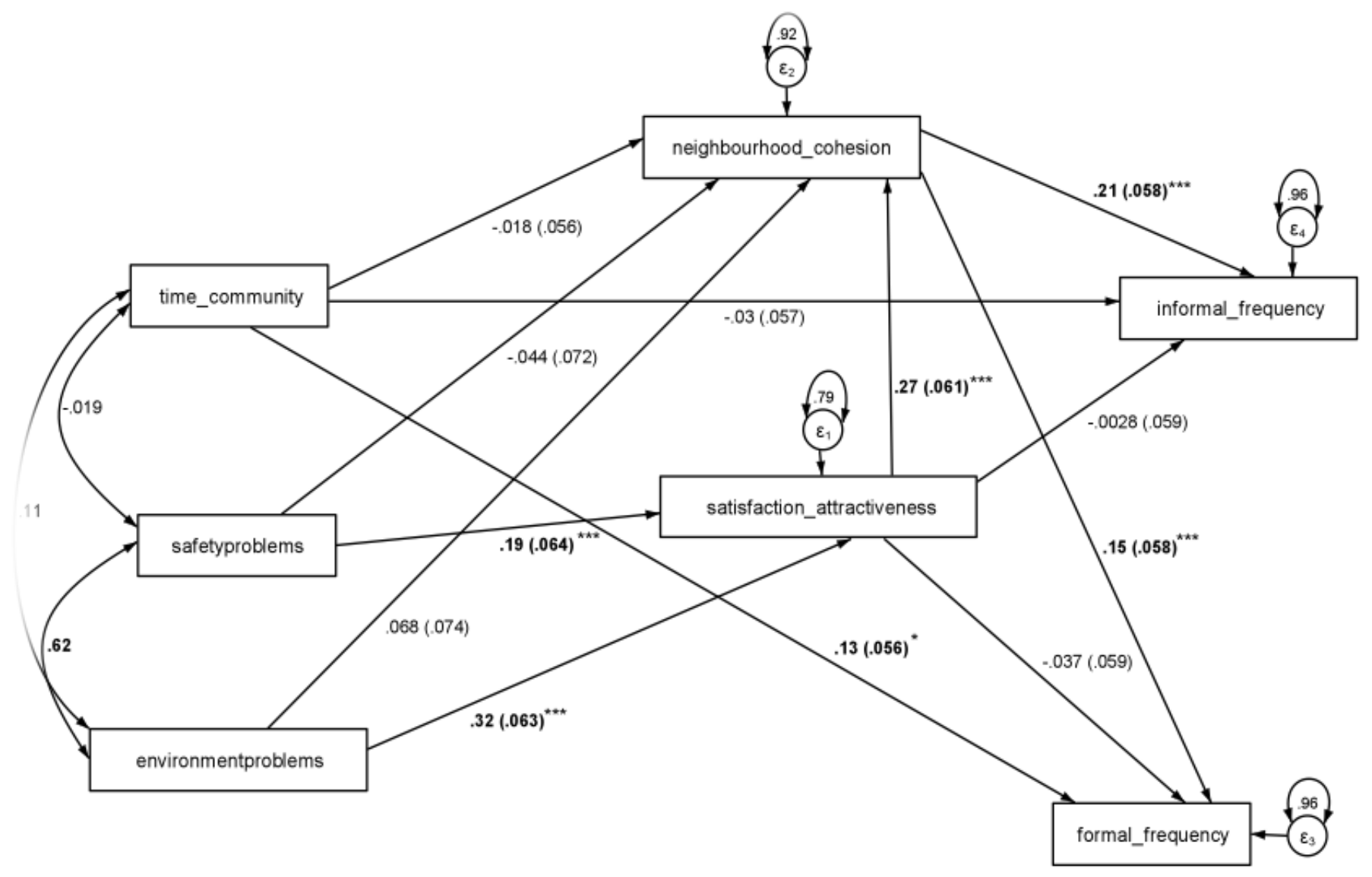

Notes: Satisfaction with neighbourhood attractiveness is included in this model; parameters are followed by standard errors; ${ }^{*} p<.05,{ }^{* * *} p<.001$

\section{DISCUSSION}

Based on what is known in the literature, this is the first study to explore the different processes through which neighbourhood perceptions relate to youth formal and informal volunteerism. Notably, in this sample, neighbourhood cohesion related most strongly to informal volunteering (i.e., helping neighbours, relatives, or friends directly). The positive perception of neighbourhood amenities was associated with greater informal volunteering intensity (but not formal), whereas perceptions of neighbourhood attractiveness did not predict any volunteer outcomes. Possible explanations for these findings are discussed in the next sections.

\section{PATHWAYS TO YOUTH VOLUNTEERISM: THE IMPORTANCE OF NEIGHBOURHOOD COHESION}

Neighbourhood cohesion may be a key element in youths' community engagement. Neighbourhoods that are more socially cohesive can cultivate social exchanges and companionship, which can consequently promote community participation (e.g., Bromell \& Cagney, 2014; Forrest \& Kearns, 2001). Conversely, weaker cohesion can reduce social interactions (Forrest \& Kearns, 2001) and decrease community participation (e.g., Latham \& Clarke, 2016). In this sample, informal volunteering may have associated more strongly with neighbourhood cohesion because this type of volunteering may in- 


\section{Pearce \& Kristjansson (2019)}

volve more reciprocity (Musick \& Wilson, 2007). Given that mutual assistance is an important facet of neighbourhood cohesion it would behove people to engage in give-and-take helping behaviours to contribute to a common collective.

Social cohesion may be greatly influenced by neighbourhood satisfaction. People who perceive greater accessibility to and availability of social amenities may experience stronger feelings of social cohesion because these amenities act as conduits to socializing (Völker et al., 2007). Similarly, positive perceptions of the built environment (e.g., aesthetics) have been associated with place attachment and social cohesion (e.g., Arnberger \& Eder, 2012; de Vries, van Dillen, Groenewegen, \& Spreeuwenberg 2013; Litt, Schmiege, Hale, Buchenau, \& Sancar, 2015). Generally, people who are more satisfied with their neighbourhood and who feel a sense of place may be more committed to informal and formal community activities (e.g., Dallago, Perkins, Santinello, Boyce, Molcho, \& Morgan, 2009; Grillo, Teixeira, \& Wilson, 2010; Manzo \& Perkins, 2006).

In this sample, perceived safety problems may not have been severe enough to influence feelings of social cohesion. One study revealed that a majority of Canadians felt that indicators of social disorder (e.g., graffiti, noise) were not a major problem in their neighbourhoods (Brennan, 2011). Further, Ottawa may be safer than many other regions in Canada. In 2016, the incident-based crime rate for all violations in Ottawa was 3,754.38 (per 100,000), which is well below the national rate of $5,904.54$ per 100,000 (Statistics Canada, 2018). This study also found that perceived neighbourhood problems were not directly related to volunteering. In contrast, earlier studies found that physical and social properties of the neighbourhood that signal disorder (e.g., cracked sidewalks, crime) limited social participation (e.g., Browning, Cagney, \& Boettner, 2016; Latham \& Clarke, 2016). However, the bulk of this literature is specific to older adults. Environmental and safety problems may be more salient to older adults' volunteering than to youths' volunteering-older adults may feel more vulnerable to crime, rely more on neighbourhood resources, and face stronger mobility challenges (Oswald \& Wahl, 2005). Volunteering may be more easily accessible to youth than older adults, and therefore youth may still engage in volunteering despite negative perceptions of environmental or safety conditions.

This study found that satisfaction with neighbourhood amenities directly predicted informal volunteering but aesthetics did not. Access to amenities and transit stops has been linked to greater interactions with neighbours (Child, JakeScoffman, Kaczynski, Forthofer, Wilcox, \& Baruth, 2016), which may be a facilitator of informal helping. Whether students perceive their neighbourhood as attractive or not may not be critical to their informal helping, because this measure may be more superficial than satisfaction with neighbourhood resources/amenities. An alternative explanation may be that youth who perceive their neighbourhoods to be less attractive may still be volunteering to improve their neighbourhood (e.g., picking up litter). These findings have implications for intervention and policy, because overall it was found that mostly social aspects of the neighbourhood (cohesion, amenities) were related to volunteerism, whereas perceptions of neighbourhood problems and physical conditions were not associated with volunteerism. Community initiatives and programs should focus on approaches to forging social cohesion among community members (e.g., meet and greet events) to bring people closer together, perhaps motivating them to volunteer in community activities.

Another finding was that neighbourhood perceptions were more strongly associated with informal volunteerism than formal volunteerism. Informal volunteering usually involves acquaintances to whom people may be attached (Stürmer, Siem, Snyder, \& Kropp, 2006; Wilhelm \& Bekkers, 2010). On the other hand, formal volunteering involves an organization that mediates the relationship between the recipients and the volunteer, thus the volunteer may feel less attached to the recipients (Stürmer et al., 2006). Formal volunteering involves a particular place and time, whereas people can carry out informal activities in "familiar areas freely" (Mitani, 2013, p. 1026). Youth who perceive strong neighbourhood cohesion may preserve this cohesion by helping neighbours and friends. Overall, neighbourhood amenities are conducive to social exchanges, which may lay fertile grounds for social cohesion, thus encouraging shared community participation. 


\section{LIMITATIONS AND FUTURE DIRECTIONS}

These analyses were based on cross-sectional data, and path analysis cannot infer causality but only test theoretical relationships. This study investigated how neighbourhood factors such as social cohesion may predict volunteerism, whereas these relationships are often bidirectional. Studies have shown that volunteering led to stronger feelings of cohesion, a stronger sense of belonging, and community attachment (e.g., Crook, Weir, Willms, \& Egdorf, 2006; Dassopoulos \& Monnat, 2011; Guo, 2014). Bidirectional relationships were not included in these models, as this would have made them non-recursive. Further, some constructs may be better represented as predictors versus outcomes (e.g., neighbourhood problems). Future studies should employ longitudinal designs to gain a clearer understanding about the direction of causation. Multilevel modelling techniques may be beneficial to directly test socio-ecological theories and explore how factors at the neighbourhood level impact on volunteerism. Future studies should also consider objective measures of the neighbourhood (e.g., census tract) and their relationship to youth volunteerism.

This study only examined neighbourhood perceptions in one Canadian city and may not be generalizable to other areas and cities. Future studies should examine whether these findings are maintained, especially in more economically and socially deprived neighbourhoods. Additionally, future studies should consider the relationship between cohesion and informal and formal volunteering in both urban and rural neighbourhoods. In some studies, rural Canadians reported a stronger sense of belonging to their community than non-rural Canadians (Kitchen, Williams, \& Chowhan, 2012; Looker, 2014), and had higher levels of trust, safety, community connections, and participation in local affairs (Onyx \& Bullen, 2000). A strong sense of belonging in rural areas fosters solidarity and social cohesion and this may translate into helping behaviour. Finally, this study included a small sample of undergraduate students with the majority being in medium to higher income groups, and, therefore, the results may not be generalizable to all youth. Youth who are pursuing higher education may have more qualifications to volunteer that attract nonprofit organizations (Wilson \& Musick, 1997), whereas low-income youth may face more barriers to volunteering and live in neighbourhoods with more environmental problems. Future studies should focus on at-risk youth and youth of lower socio-economic status to determine whether their living conditions have different impacts on their volunteering. Further, it is also important to explore neighbourhood perceptions and volunteerism among high school students, because adolescence is a pivotal period for prosocial development.

\section{CONCLUSION}

This study contributes to the volunteer literature by showing that youth perceptions of their neighbourhood may be important to their volunteering intensities, at least in one Canadian city. In the Canadian context, as the composition of neighbourhoods continually evolves and becomes more diversified, it is essential to understand ways to avoid social exclusion and ensure youth have a sense of community. This research could be of potential value to urban planners, developers, and government agencies, as youth may invest more into their communities if more facilities are available to them, supporting the notion that it takes a community to build a community. Nonprofits and community stakeholders should also endorse strategies that strengthen social cohesion in the broader environment when trying to recruit young volunteers, because a high sense of community belonging may increase youths' proclivity to engage in acts of philanthropy. This not only has benefits for the individual but can benefit entire neighbourhoods through a constant flow of social capital, whereby strong social cohesion can stir greater participation, thus sustaining, strengthening, and revitalizing communities. Continued research in this area will pursue a more panoramic view of youth volunteerism by focusing not only on individual-level determinants but also the environmental influences of helping behaviour, thus potentially warranting intervention at the neighbourhood level to promote community involvement. 


\section{Pearce \& Kristjansson (2019)}

\section{WEBSITES}

FluidSurveys, http://fluidsurveys.com/

Stata software version 14.0, https://www.stata.com/stata14/

\section{REFERENCES}

Adriaanse, C.C.M. (2007). Measuring residential satisfaction: A residential environmental satisfaction scale (RESS). Journal of Housing and the Built Environment, 22(3), 287-304. doi:10.1007/s10901-007-9082-9

Ahn, S., Phillips, K.L., Smith, M.L., \& Ory, M.G. (2011). Correlates of volunteering among aging Texans: The roles of health indicators, spirituality, and social engagement. Maturitas, 69(3), 257-262. doi:10.1016/j.maturitas .2011.04.002

Aiello, A., Ardone, R.G., \& Scopelliti, M. (2010). Neighbourhood planning improvement: Physical attributes, cognitive and affective evaluation and activities in two neighbourhoods in Rome. Evaluation and Program Planning, 33(3), 264-275. doi:10.1016/j.evalprogplan.2009.10.004

Alesina, A., \& La Ferrara, E. (2005). Ethnic diversity and economic performance. Journal of Economic Literature, 43(3), 762-800. doi: 10.1257/002205105774431243

Andersen, H.S. (2008). Why do residents want to leave deprived neighbourhoods? The importance of residents' subjective evaluations of their neighbourhood and its reputation. Journal of Housing and the Built Environment, 23(1), 79-101. doi:10.1007/s10901-008-9109-x

Arnberger, A., \& Eder, R. (2012). The influence of green space on community attachment of urban and suburban residents. Urban Forestry \& Urban Greening, 11(1), 41-49. doi:10.1016/j.ufug.2011.11.003

Ballard, P.J., Malin, H., Porter, T.J., Colby, A., \& Damon, W. (2015). Motivation for civic participation among diverse youth: More similarities than differences. Research in Human Development, 12(1-2), 63-83. doi: 10.1080 /15427609.2015.1010348

Bekkers, R. (2007). Intergenerational transmission of volunteering. Acta Sociologica, 50(2), 99-114. doi:0.1177 10001699307077653

Bowling, A., \& Stafford, M. (2007). How do objective and subjective assessments of neighbourhood influence social and physical functioning in older age? Findings from a British survey of ageing. Social Science \& Medicine, 64(12), 2533-2549. doi:10.1016/j.socscimed.2007.03.009

Braubach, M. (2007). Residential conditions and their impact on residential environment satisfaction and health: Results of the WHO large analysis and review of European housing and health status (LARES) study. International Journal of Environment and Pollution, 30(3-4), 384-403. doi:10.1504/IJEP.2007.014817

Brennan, S. (2011). Canadians' perceptions of personal safety and crime, 2009 (Statistics Canada Catalogue no. 85002-x). URL:http://www.statcan.gc.ca/pub/85-002-x/2011001/article/11577-eng.htm\#a7 [September 15, 2018].

Bromell, L., \& Cagney, K.A. (2014). Companionship in the neighborhood context: Older adults' living arrangements and perceptions of social cohesion. Research on Aging, 36(2), 228-243. doi:10.1177/0164027512475096

Browne, M.W., \& Cudeck, R. (1992). Alternative ways of assessing model fit. Sociological Methods \& Research, 21(2), 230-258. doi:10.1177/0049124192021002005

Browning, C.R., Cagney, K.A., \& Boettner, B. (2016). Neighborhood, place, and the life course. In M.J. Shanahan, J.T. Mortimer, \& M.J. Kirkpatrick (Eds.), Handbook of the life course (pp. 597-620). Chicago, LL: Springer International Publishing.

Bruhn, J. (2009). The concept of social cohesion. In J. Bruhn (Ed.), The group effect: Social cohesion and health outcomes (pp. 31-48). Boston, MA: Springer. doi:10.1007/978-1-4419-0364-8_2

Buckner, J.C. (1988). The development of an instrument to measure neighbourhood cohesion. American Journal of Community Psychology, 16(6), 771-791. doi: 10.1007/BF00930892 


\section{Pearce \& Kristjansson (2019)}

Buffel, T., De Donder, L., Phillipson, C., Dury, S., De Witte, N., \& Verté, D. (2013). Social participation among older adults living in medium-sized cities in Flanders, Belgium: The role of neighborhood perceptions. Health Promotion International, 29(4), 655-668. doi:10.1093/heapro/dat009

Carson, E.D. (1999). On defining and measuring volunteering in the United States and abroad. Law and Contemporary Problems, 64(4), 67-71. URL: http://scholarship.law.duke.edu/cgi/viewcontent.cgi?article=1147\&context=Icp [December 10, 2018].

Chan, J., To, H.-P., \& Chan E. (2006). Reconsidering social cohesion: developing a definition and analytical framework for empirical research. Social Indicators Research, 75(2), 273-302. doi: 10.1007/s11205-005-2118-1

Child, S.T., Jake-Schoffman, D.E., Kaczynski, A.T., Forthofer, M., Wilcox, S., \& Baruth, M. (2016). Neighbourhood attributes associated with the social environment. American Journal of Health Promotion, 30(8), 634-637. doi: 10.4278/ajhp.140307-ARB-99

Clarke, P.J., Ailshire, J.A., Nieuwenhuijsen, E.R., \& de Kleijn-de Vrankrijker, M.W. (2011). Participation among adults with disability: The role of the urban environment. Social Science \& Medicine, 72(10), 1674-1684. doi: 10.1016/j.socscimed.2011.03.025

Costa, D.L., \& Kahn, M.E. (2003). Civic engagement and community heterogeneity: An economist's perspective. Perspectives on Politics, 1(1), 103-111. doi:10.1017/S1537592703000082.

Crook, J., Weir, R., Willms, D., \& Egdorf, T. (2006). Experiences and benefits of volunteering in a community AIDS organization. The Journal of the Association of Nurses in AIDS Care, 17(4), 39-45. doi:10.1016/j.jana.2006.05.002

Dallago L., Perkins D., Santinello M., Boyce, W.T., Molcho, M., \& Morgan, A. (2009). Adolescent place attachment, social capital, and perceived safety: A comparison of 13 countries. American Journal of Community Psychology, 44(1-2), 148-160. doi:10.1007/s10464-009-9250-z

Dassopoulos, A., \& Monnat, S.M. (2011). Do perceptions of social cohesion, social support, and social control mediate the effects of local community participation on neighbourhood satisfaction? Environment and Behaviour, 43(4), 546-565. doi:10.1177/0013916510366821

Dempsey, N. (2008). Does quality of the built environment affect social cohesion? Urban Design and Planning, 161(3), 105-114. doi: 10.1680/udap.2008.161.3.105

De Vries, S., van Dillen, S.M.E., Groenewegen, P.P., \& Spreeuwenberg, P. (2013). Streetscape greenery and health: stress, social cohesion and physical activity as mediators. Social Science \& Medicine, 94, 26-33. doi: 10.1016 j.s.socscimed.2013.06.030

Duke, N.N., Borowsky, I.W., \& Pettingell, S.L (2012). Adult perceptions of neighbourhood: Links to youth engagement. Youth \& Society, 44(3), 408-430. doi:10.1177/0044118X11402852

Dury, S., Willems, J., De Witte, N., De Donder, L., Buffel, T., \& Verté, D. (2014). Municipalityand neighbourhood influences on volunteering in later life. Journal of Applied Gerontology, 35(6), 601-626. doi: 10.1177/0733464814533818

Eamon, M.K., \& Mulder, C. (2005). Predicting antisocial behavior among Latino young adolescents: An ecological systems analysis. American Journal of Orthopsychiatry, 75(1), 117-127. doi: 10.1037/0002-9432.75.1.117

Ellaway A., Macintyre S., \& Kearns A. (2001). Perceptions of place and health in socially contrasting neighbourhoods. Urban Studies, 38(12), 2299-2316. doi:10.1080/00420980120087171

European Commission (2013). Quality of life in cities: Perception survey in 79 European cities (Flash Eurobarometer 366, Catalogue No. KN-03-13-433-EN-C). URL: http://ec.europa.eu/regional_policy/sources/docgener/studies/pdf lurban/survey2013_en.pdf [August 1, 2018].

Feldman, A., \& Matjasko, J.L. (2005). The role of school-based extracurricular activities in adolescent development: A comprehensive review and future directions. Review of Educational Research, 75(2), 159-210. doi:10.3102/00346543075002159

Finkelstein, M.A. (2012). Dispositional correlates of informal volunteering. Current research in Social Psychology, 18(6), 60-69. doi:10.1.1.364.1040 


\section{Pearce \& Kristjansson (2019)}

Finkelstein, M.A., \& Brannick, M.T. (2007). Applying theories of institutional helping to informal volunteering: Motives, role identity, and prosocial personality. Social Behaviour and Personality: An International Journal, 35(1), 101-114. doi:10.2224/sbp.2007.35.1.101

Fleury-Bahi, G., Felonneau, M.-L., \& Marchand, D. (2008). Processes of place identification and residential satisfaction. Environment and Behavior, 40(5), 669-682. doi:10.1177/0013916507307461

Forehand, R., \& Jones, D.J. (2003). Neighbourhood violence and coparent conflict: Interactive influence on child psychosocial adjustment. Journal of Abnormal Child Psychology, 31(6), 591-604. doi:10.1023/A:1026206122470

Forrest, R. \& Kearns, A. (2001). Social cohesion, social capital, and the neighbourhood. Urban Studies, 38(12), 2125-2143. doi: $10.1080 / 00420980120087081$

Gardner, M., Roth, J., \& Brooks-Gunn, J. (2008). Adolescents' participation in organized activities and developmental success 2 and 8 years after high school: Do sponsorship, duration, and intensity matter? Developmental Psychology, 44(3), 814-830. doi:10.1037/0012-1649.44.3.814

Gibson, T. (2008). Religion and civic engagement among America's youth. The Social Science Journal, 45(3), 504-514. doi:10.1016/j.soscij.2008.07.007

Glass, T.A., \& Balfour, J.L. (2003). Neighbourhoods, aging, and functional limitations. In I. Kawachi \& L.F. Berkman (Eds.), Neighbourhoods and health (pp. 303-334). Oxford Scholarship Online. doi:10.1093/acprof:oso/97801951 38382.001.0001

Grillo, M.C, Teixeira, M.A, \& Wilson, D.C. (2010). Residential satisfaction and civic engagement: Understanding the causes of community participation. Social Indicators Research, 97(3), 451-466. doi:10.1007/s11205-009-9511-0

Grzeskowiak, S., Sirgy, M.J., \& Widgery, R. (2003). Residents' satisfaction with community services: Predictors and outcomes. The Journal of Regional Analysis and Policy, 33(2), 1-36.

Guo, S. (2014). Immigrants as active citizens: Exploring the volunteering experience of Chinese immigrants in Vancouver. Globalisation, Societies and Education, 12(1), 51-70. doi:10.1080/14767724.2013.858527

Hand, C., Law, M., Hanna, S., Elliot, S., \& McColl, M.A. (2012). Neighbourhood influences on participation in activities among older adults with chronic health conditions. Health \& Place, 18(4), 869-876. doi:10.1016/j.healthplace.2012.03.004

Handy, F., Cnaan, R.A., Hustinx, L., Kang, C., Brudney, J.L., Haski-Leventhal, D., Holmes, K., Meijs, L.C.M.P., Pessie, A.B., Rande, B., Yamauchi, N., \& Zrinscak, S. (2010). A cross-cultural examination of student volunteering: Is it all about resume building? Nonprofit and Voluntary Sector Quarterly, 39(3), 498-523. doi:10.1177/0899764009344353

Hartman, J.J. (1981). Group cohesion and the regulation of self-esteem. In H. Kellerman (Ed.), Group cohesion: Theoretical and clinical perspectives (pp. 255-267). New York, NY: Grune \& Stratton.

Hellman, C.M., Hoppes, S., \& Ellison, G.C. (2006). Factors associated with college student intent to engage in community service. The Journal of Psychology, 140(1), 29-39. doi:10.3200/JRLP.140.1.29-39

Holdsworth, C., \& Quinn, J. (2010). Student volunteering in English higher education. Studies in Higher Education, 35(1), 113-127. doi:10.1080/03075070903019856

Hooper, D., Coughlan, J., \& Mullen, M. (2008). Structural equation modelling: Guidelines for determining model fit. Electronic Journal of Business Research Methods, 6(1), 53-60. URL: http://arrow.dit.ie/cgi/viewcontent.cgi?article $=1001 \&$ context=buschmanart [July 14, 2018].

Hovbrandt, P., Stahl, A., Iwarsson, S., Horstmann, V., \& Carlsson, G. (2007). Very old people's use of the pedestrian environment: functional limitations, frequency of activity and environmental demands. European Journal of Ageing, 4(4), 201-211. doi:10.1007/s10433-007-0064-2

Hu, L.-t., \& Bentler, P.M. (1999). Cutoff criteria for fit indexes in covariance structure analysis: Conventional criteria versus new alternatives. Structural Equation Modeling, 6(1), 1-55. doi:10.1080/10705519909540118

Kass, R.E., \& Raftery, A.E. (1995). Bayes factors. Journal of the American Statistical Association, 90(430), 773-795. URL: https://www.stat.washington.edu/raftery/Research/PDF/kass1995.pdf [September 10, 2018]. 


\section{Pearce \& Kristjansson (2019)}

Kegler, M.C., Oman, R.F., Vesely, S.K., McLeroy, K.R., Aspy, C.B., Rodine, S., \& Marshall, L. (2005). Relationships among youth assets and neighborhood and community resources. Health Education \& Behavior, 32(3), 380-397. doi:10.1177/1090198104272334

Kim, J., \& Morgül, K. (2017). Long-term consequences of youth volunteering: Voluntary versus involuntary service. Social Science Research, 67, 160-175. doi:10.1016/j.ssresearch.2017.05.002

King, D. (2008). Neighborhood and individual factors in activity in older adults: Results from the neighborhood and senior health study. Journal of Aging \& Physical Activity, 16(2), 144-170. doi:10.1123/japa.16.2.144

Kitchen, P., Williams, A., \& Chowhan, J. (2012). Sense of community belonging and health in Canada: A regional analysis. Social Indicators Research, 107(1), 103-126. doi:10.1007/s11205-011-9830-9

Kline, R.B. (2005). Principles and practice of structural equation modeling, second edition. New York, NY: The Guilford Press.

Latham, K., \& Clarke, P.J. (2016). Neighborhood disorder, perceived social cohesion, and social participation among older Americans: Findings from the National Health \& Aging Trends Study. Journal of Aging and Health, 30(1), 326. doi:10.1177/089826431666593

Lee, Y.-J., \& Brudney, J.L. (2012). Participation in formal and informal volunteering: Implications for volunteer recruitment. Nonprofit Management and Leadership, 23(2), 159-180. doi:10.1002/nml.21060

Lenzi, M., Vieno, A., Perkins, D.D., Santinello, M., Elgar, F.J., Morgan, A., \& Mazzardis, S. (2012). Family affluence, school and neighborhood contexts and adolescents' civic engagement: A cross-national study. American Journal of Community Psychology, 50(1-2), 197-210. doi:10.1007/s10464-012-9489-7

Lerner, R.M., Lerner, J.V., Almerigi, J.B, Theokas, C., Phelps, E., Gestsdottir, S.,... von Eye, A. (2005). Positive youth development, participation in community youth development programs, and community contributions of fifth grade adolescents: Findings from the first wave of the 4-H Study of Positive Youth Development. Journal of Early Adolescence, 25(1), 17-71. doi:10.1177/0272431604272461

Letki, N. (2008). Does diversity erode social cohesion? Social capital and race in British neighbourhoods. Political Studies, 56(1), 99-126. doi: 10.1111/j.14679248.2007.00692.x

Litt, J.S., Schmiege, S.J., Hale, J.W., Buchenau, M., \& Sancar, F. (2015). Exploring ecological, emotional and social levers of self-rated health for urban gardeners and non-gardeners: A path analysis. Social Science \& Medicine, 144, 1-8. doi:10.1016/j.socscimed.2015.09.004

Looker, E.D. (2014). Supportive communities and a sense of belonging in rural and non-rural communities in Canada. The Journal of Rural and Community Development, 9(4), 163-180. URL: http://journals.brandonu.ca/jrcd larticle/view/1185/273 [August 20, 2018].

Lorenc, T., Clayton, S., Neary, D., Whitehead, M., Petticrew, M., Thomson, H., Cummins, S., Sowden, A., \& Renton, A. (2012). Crime, fear of crime, environment, and mental health and wellbeing: Mapping review of theories and causal pathways. Health \& Place, 18(4), 757-765. doi:10.1016/j.healthplace.2012.04.001

MacCallum, R.C., Browne, M.W., \& Sugawara, H.M. (1996). Power analysis and determination of sample size for covariance structure modeling. Psychological Methods, 1(2), 130-149. doi: 10.1037//1082-989X.1.2.130

MacKinnon, D.P., Lockwood, C.M., \& Williams, J. (2004). Confidence limits for the indirect effect: Distribution of the product and resampling methods. Multivariate Behavioral Research, 39(1), 99-128. doi:10.1207/s15327906mbr3901_4

MacNeela, G., \& Gannon, N. (2014). Process and positive development: An interpretive phenomenological analysis of university student volunteering. Journal of Adolescent Research, 29(3), 407-436. doi:10.1177/0743558413510968

Manzo L.C., \& Perkins, D.D. (2006). Finding common ground: the importance of place attachment to community participation and planning. Journal of Planning Literature, 20(4), 335-350. doi: 10.1177/0885412205286160

McLellan, J.A., \& Youniss, J. (2003). Two systems of youth service: Determinants of voluntary and required youth community service. Journal of Youth and Adolescence, 32(1), 47-58. doi:10.1023/A:1021032407300

McMillan, D.W., \& Chavis, D.M. (1986). Sense of community: A definition and theory. Journal of Community Psychology, 14(1), 6-23. doi: 10.1002/1520-6629(198601)14:1<6::AID-JCOP2290140103>3.0.C0;2-I 


\section{Pearce \& Kristjansson (2019)}

McPherson, M., Smith-Lovin, L., \& Cook, J.M. (2001). Birds of a feather: Homophily in social networks. Annual Review of Sociology, 27, 415-444. doi:10.1146/annurev.soc.27.1.415

Mitani, H. (2013). Influences of resources and subjective dispositions on formal and informal volunteering. Voluntas, 25(4), 1022-1040. doi: 10.1007/s11266-013-9384-3

Musick, M.A., \& Wilson, J. (2007). Volunteers: A social profile. Bloomington, IN: Indiana University Press.

Obasaju, M.A., Palin, F.L., Jacobs, C., Anderson, P., \& Kaslow, N.J. (2009). Won't you be my neighbor? Using an ecological approach to examine the impact of community on revictimization. Journal of Interpersonal Violence, 24(1), 38-53. doi: 10.1177/0886260508314933

Okun, M.A., \& Michel, J. (2006). Sense of community and being a volunteer among the young-old. Journal of Applied Gerontology, 25(2), 173-188. doi: 10.1177/0733464806286710

Onyx, J., \& Bullen, P. (2000). Measuring social capital in five communities. The Journal of Applied Behavioral Sciences, 36(1), 23-42. doi:10.1177/0021886300361002

Oswald F., \& Wahl, H.-W. (2005). Dimensions of the meaning of home in later life. In G.D. Rowles \& H. Chaudhury (Eds.), Home and identity in late life — International perspectives (pp. 21-45). New York, NY: Springer.

Pancer, M., \& Pratt, M.W. (1999). Social and family determinants of community service involvement in Canadian Youth. In M. Yates \& J. Youniss (Eds.), Roots of civic identity: International perspectives on community service and activism in youth. Cambridge, UK: Cambridge University Press.

Parkes, A., Kearns, A., \& Atkinson, R. (2002). What makes people dissatisfied with their neighbourhoods? Urban Studies, 39(13), 2413-2438. doi:10.1080/0042098022000027031

Plybon, L.E, Edwards L., Butler D., Belgrave, F.Z, \& Allison, K.W. (2006). Examining the link between neighborhood cohesion and school outcomes: The role of support coping among African American adolescent girls. Journal of Black Psychology, 29(4), 393-407. doi:10.1177/0095798403256892

Preacher, K.J., \& Hayes, A.F. (2004). SPSS and SAS procedures for estimating indirect effects in simple mediation models. Behavior Research Methods, Instruments, \& Computers, 36(4), 717-731. doi:10.3758/BF03206553

Preacher, K.J., \& Hayes, A.F. (2008). Asymptotic and resampling strategies for assessing and comparing indirect effects in multiple mediator models. Behavior Research Methods, 40(3), 879-891. doi:10.3758/BRM.40.3.879

Prezza, M., Amici, M., Roberti, T., \& Tedeschi, G. (2001). Sense of community referred to the whole town: Its relations with neighboring, loneliness, life satisfaction, and area of residence. Journal of Community Psychology, 29(1), 29-52. doi: 10.1002/1520-6629(200101)29:1<29::AID-JCOP3>3.0.CO;2-C

Putnam, R.D. (2000). Bowling alone: The collapse and revival of American community. New York, NY: Simon and Schuster Paperbacks.

Putnam, R.D. (2007). E pluribus unum: Diversity and community in the twenty-first century — The 2006 Johan Skytte Prize lecture. Scandinavian Political Studies, 30(2), 137-174. doi:10.1111/j.1467-9477.2007.00176.x

Richard, L., Gauvin, L., Gosselin, C., \& LaForest, S. (2008). Staying connected: Neighbourhood correlates of social participation among older adults living in an urban environment in Montréal, Quebec. Health Promotion International, 24(1), 46-57. doi:10.1093/heapro/dan039

Sampson, R.J. (1997). The embeddedness of child and adolescent development: A community-level perspective on urban violence. In J. McCord (Ed.), Violence and childhood in the inner city (pp. 31-77). Cambridge, UK: Cambridge University Press.

Sampson, R.J., Morenoff, J.D., \& Gannon-Rowley, T. (2002). Assessing 'neighbourhood effects': Social processes and new directions in research. Annual Review of Sociology, 28, 443-478. doi:10.1146/annurev.soc.28.110601.141114

Sampson, R.J., \& Raudenbush, S.W. (1999). Systematic social observation of public spaces: A new look at disorder in urban neighbourhoods. American Journal of Sociology, 105(3), 603-651. doi:10.1086/210356

Sampson, R.J., Raudenbush, S.W, \& Earls, F. (1997). Neighborhoods and violent crime: A multilevel study of collective efficacy. Science, 277(5328), 918-924. doi:10.1126/science.277.5328.918 


\section{Pearce \& Kristjansson (2019)}

Sarason, S.B. (1974). The psychological sense of community: Prospects for a community psychology. San Francisco, CA: Jossey-Bass.

Schumacker, R.E., \& Lomax, R.G. (2004). A beginner's guide to structural equation modeling second edition. Mahwah, $\mathrm{NJ}$ : Lawrence Erlbaum Associates.

Siu, A.M.H., Shek, D.T.L., \& Law, B. (2012). Prosocial norms as a positive youth development construct: A conceptual review. The Scientific World Journal, 2012(3), 19-27. doi:10.1100/2012/832026

Snyder, M., \& Omoto, A.M. (2007). Social action. In A.W. Kruglanski \& E.T. Higgins (Eds.), Social Psychology: A handbook of basic principles (2nd ed.), (pp. 940-961), New York, NY: Guilford Press.

Soroka, S.N., Johnston, R., \& Banting, K. (2006). Ties that bind? Social cohesion and diversity in Canada. URL: http: //irpp.org/research-studies/ties-that-bind/ [December 14, 2018].

Stanley, D. (2003). What do we know about social cohesion: The research perspective of the federal government's social cohesion research network. Canadian Journal of Sociology, 28(1), 5-17. doi:10.2307/3341872

Statistics Canada. (2007). Microdata user guide: Canada Survey of Giving, Volunteering and Participating, 2007. Ottawa, ON: Statistics Canada.

Statistics Canada (2018). Incident-based crime statistics, by detailed violations (Table 35-10-0177-01).URL: https:// www150.statcan.gc.ca/t1/tbl1/en/tv.action?pid=3510017701\&pickMembers\%5B0\%5D=1.18\&pickMembers $\% 5 B 1$ $\% 5 \mathrm{D}=2.1$ [September 4, 2018].

Stolle, D., Soroka, S., \& Johnston, R. (2008). When does diversity erode trust? Neighborhood diversity, interpersonal trust and the mediating effect of social interactions. Political Studies, 56(1), 57-75. doi:10.1111/j.1467-9248.2007.00717.x

Stürmer, S., Siem, B., Snyder, M., \& Kropp, A. (2006). Empathy-motivated helping: The moderating role of group membership. Personality and Social Psychology Bulletin, 32(7), 943-956. doi:10.1177/0146167206287363

Sundeen, R.A., \& Raskoff, S.A. (2000). Ports of entry and obstacles: Teenagers' access to volunteer activities. Nonprofit Management and Leadership, 11(2), 179-197. doi:10.1002/nml.11204

Tessier, S., Minh-Nguyet, N., \& Gagnon, K. (2006). Youth volunteerism: Research report. URL: http://www .imaginecanada.ca/sites/default/files/www/en/library/kdccdc/laval_youthstudy_report.pdf [August 20, 2018].

Thacker, J.W., Fields, M.W., \& Tetrick, L.E. (1989). The factor structure of union commitment: An application of confirmatory factor analysis. Journal of Applied Psychology, 74(2), 228-232. doi:10.1037/0021-9010.74.2.228

Völker, B., Flap, H., \& Lindenberg, S. (2007). When are neighbourhoods communities? Community in Dutch neighbourhoods. European Sociological Review, 23(1), 99-114. doi:10.1093/esr/jcl022

Wheaton, B., Muthén, B., Alwin, D.F., \& Summers, G. (1977). Assessing reliability and stability in panel models. Sociological Methodology, 8(1), 84-136. URL: https://www.statmodel.com/bmuthen/articles/Article_001.pdf [October 8, 2018].

Wilhelm, M.O., \& Bekkers, R. (2010). Helping behavior, dispositional empathic concern, and the principle of care. Social Psychology Quarterly, 73(1), 11-32. doi:10.1177/0190272510361435

Williams, J., \& MacKinnon, D.P. (2008). Resampling and distribution of the product methods for testing indirect effects in complex models. Structural Equation Modeling, 51(1), 23-51. doi:10.1080/10705510701758166

Wilson, J. (2000). Volunteering. Annual Review of Sociology, 26, 215-240. doi:10.1146/annurev.soc.26.1.215

Wilson, J.Q., \& Kelling, G.L. (1982). Broken windows: The police and neighbourhood safety. Atlantic Monthly, 249, 29-38. Wilson, J., \& Musick, M.A. (1997). Who cares? Toward an integrated theory of volunteer work. American Sociological Review, 62(5), 694-713. doi:10.2307/2657355

Young, A.F., Russell, A., \& Powers, J.R. (2004). The sense of belonging to a neighbourhood: Can it be measured and is it related to health and well being in older women? Social Science \& Medicine, 59(12), 2627-2637. doi:10.1016 /j.socscimed.2004.05.001 
Pearce \& Kristjansson (2019)

Zaff, J.F., Moore, K.A., Papillo, A.R., \& Williams, S. (2003). Implications of extracurricular activity participation during adolescence on positive outcomes. Journal of Adolescent Research, 18(6), 599-630. doi:10.1177/074355840325477

\section{ABOUT THE AUTHORS / LES AUTEURS}

Sean Pearce has a PhD in Psychology from the University of Ottawa in Ottawa, Ontario. Email : sean.pearce40@gmail.com .

Elizabeth Kristjansson is a Professor of Psychology at the University of Ottawa in Ottawa, Ontario. Email : kristjan@uottawa.ca . 